\title{
MAKNA SEMIOTIK DALAM NOVEL ANOMIE KARYA RILDA A. OE. TANEKO
}

Semiotic Meanings in the Rilda A. Oe. Taneko's novel, Anomie

\author{
Erwin Wibowo \\ Kantor Bahasa Lampung \\ Pos-el: kbpl_2006@yahoo.com, erwin.wibowo@ymail.com
}

\section{Naskah Diterima 4 Oktober 2017 -Direvisi Akhir 28 November 2017 -Disetujui 28 November 2017 doi.org/10.26499/jentera.v6i2.472}

\begin{abstract}
Abstrak: Penelitian ini bertujuan untuk mendeskripsikan makna semiotik yang terdapat dalam novel Anomie karya Rilda A.Oe. Taneko. Metode yang digunakan adalah metode deskriptif, dengan pendekatan semiotic Pierce yang meliputi ikon, indeks dan simbol. Sumber data yang dipakai dalam penelitian ini adalah novel Anomie karya Rilda A.Oe. Taneko dengan mengamati data-data ikon, indeks dan simbol yang tercermin dalam kutipan-kutipan tersebut, dan beberapa buku yang dijadikan referensi dalam penelitian ini. Teknik pengambilan data menggunakan teknik studi pustaka. Permasalahan yang akan dipecahkan dalam penelitian ini adalah (1) mengidentifikasi ikon, indeks dan simbol semiotik yang terdapat dalam novel Anomie karya Rilda A.Oe. Taneko, dan (2) mendeskripsikan ikon, indeks dan simbol semiotik yang terdapat dalam novel Anomie karya Rilda A.Oe. Taneko. Hasil penelitian ini menunjukan bahwa novel Anomie karya Rilda A.Oe. Taneko terdapat simbol semiotik yang meliputi ikon berupa lembaga pendidikan, lembaga sosial, dan tempat hiburan. Indeks dalam novel ini berupa kekuasaan, keserakahan, kesombongan dan kekhawatiran tokoh-tokohnya. Simbol pada novel ini meliputi simbol kekayaan, simbol pengorbanan, dan simbol cinta kasih.
\end{abstract}

Kata Kunci: Semiotik, Ikon, Indeks, Simbol, Novel

Abstract: The aim of the research is to describe semiotic meanings in the Rilda A.Oe. Taneko's novel, Anomie. The method used is decriptive method with semiotic approach by Pierce which includes icons, indexes, and symbols. The data source used in this research is the novel Anomie written by Rilda A.Oe. Taneko by investigating the data of symbols reflected in the quotations, and some books which are treated as references in this research. The collecting data technique is conducted by using literary review. The problems which are elaborated in this research are 1)identifying icons, indexes, and symbols semiotic in the novel Anomie written by Rilda A.Oe. Taneko, 2) describing icons, indexes, and symbols semiotic in the Rilda A.Oe. Taneko's novel, Anomie. The results of this study show the novel Anomie by Rilda A.Oe. Taneko there is a semiotic symbol that includes the icon of educational institutions, social institutions, and entertainment venues. This novel index belongs to the strength, greed, pride and character figures. The symbols of this novel include symbols of wealth, sacrificial symbols, and symbols of love.

Key words: semiotic, icons, indexes, symbol, novel

How to cite: Wibowo, Erwin. (2017). Makna Semiotik Dalam Novel Anomie Karya Rilda A. Oe. Taneko. Jentera: Jurnal Kajian Sastra, 6 (2), 129-18 (doi.org/10.26499/jentera.v6i2.472) 


\section{Pendahuluan}

Sastra merupakan salah satu cabang seni warisan peradaban dunia sejak ribuan tahun yang lalu. Kehadiran sastra dalam masyarakat dunia tidak bisa ditolak dan terus berkembang sesuai dengan zamannya. Hingga saat ini sastra tidak saja dinilai sebagai sebuah karya seni yang memiliki budi, imajinasi, dan emosi, tetapi telah dianggap sebagai suatu karya kreatif yang dimanfaatkan sebagai konsumsi intelektual di samping konsumsi emosi (Semi 1990: 1).

Secara garis besar karya sastra dibagi menjadi tiga, yaitu puisi, prosa, dan drama. Karya sastra merupakan hasil karya manusia yang mengandung imajinasi dengan menggunakan bahasa sebagai medianya. Sastra itu sendiri lahir disebabkan oleh dorongan manusia untuk menunjukan kreativitasnya. Sastra di Indonesia dewasa ini mengalami perkembangan yang pesat. Sastra kekinian lahir dengan bentuk yang beragam. Kemunculan karya sastra di dunia ini memunculkan pula kajiankajian yang menjadi karya sastra sebagai objeknya. Hal ini karena karya sastra memiliki maksud tersirat yang ingin disampaikan oleh penulisnya.

Salah satu tujuan memahami karya sastra dengan pendekatan objektif adalah memahami simbol budaya yang ada dalam karya sastra itu sendiri. Abrams dalam Endraswara (2008: 9) menjelaskan bahwa pendekatan objektif berfokus pada karya sastra itu sendiri yang biasanya disebut strukturalisme atau intrinsik. Jika pembaca tidak memperhatikan pendekatan dalam memahami karya sastra, dia tidak akan menemukan makna simbol-simbol yang terdapat dalam karya sastra itu meskipun telah membaca karya itu secara intensif dan berulang-ulang. Oleh sebab itu, dengan memahami karya sastra melalui pendekatan objektif pembaca dapat menemukan berbagai makna dari simbol-simbol yang terdapat dalam karya sastra.

Karya sastra sebagai simbol yang merupakan bentuk untuk menandai sesuatu yang lain di luar perwujudan bentuk simbolik itu sendiri. Simbol tidak dapat disikapi secara isolatif, terpisah dari hubungan asosiatifnya, dengan simbol lainnya (Aminuddin, 1995:189). Simbol merupakan seluruh kegiatan mental manusia yang dianggap sebagai satu-satunya media yang didasari oleh sebuah penalaran. Bahasa kemudian hanya dijadikan sebagai salah satu bentuk kegiatan atau sebuah ungkapan simbolis dengan kegiatan simbolis lainnya.

Novel merupakan karya sastra yang biasanya berisikan tentang kehidupan masyarakat, novel juga merupakan karya sastra yang di dalamnya memuat nilai-nilai estetika dan nilainilai kehidupan, tidak jarang pula novel merupakan kritik sosial dan gambaran sejarah yang pernah terjadi di masyarakat.

Setelah rezim orde baru runtuh, khazanah sastra di Indonesia diwarnai dengan kemunculan karya sastra yang berisikan kritik sosial, fakta sejarah yang diungkapkan melalui novel, dan karya sastra lainnya. Tidak hanya itu, novel dengan penceritaan yang dahulu dianggap tabu juga sempat meramaikan sastra Indonesia, sebut saja novel Saman karya Ayu Utami yang menggambarkan keadaan masyarakat Indonesia pada akhir pemerintahan Orde Baru, dan 
masih banyak lagi penulis yang mencoba mengkritik pemerintah orde baru melalui karya sastranya.

Salah satu novel yang mengandung nilai-nilai kehidupan, kritik sosial dan juga mengandung niai-nilai sejarah adalah novel Anomie karya Rilda A.Oe. Taneko. Novel ini juga bercerita tentang bagaimana orang-orang yang berkuasa pada zaman orde baru, hingga peristiwa digulingkannya penguasa saat itu oleh pergerakan mahasiswa dan masyarakat yang disebut reformasi. Peristiwa-peristiwa kemanusiaan juga dengan apik diangkat oleh Rilda dalam novel Anomie ini. Tragedi Talangari yang hingga kini belum kunjung tuntas, seakan mengingatkan pembaca bagaimana tragedi yang menghilangkan ratusan nyawa tersebut.

Selain mengungkapkan fakta tentang orde baru, novel ini juga menggambarkan tentang lika-liku kehidupan seorang tokoh yang bernama Rosie. Dalam novel ini tokoh Rosie digambarkan sebagai perempuan yang mencoba untuk mencari keadilan bagi dirinya. Peristiwa demi peristiwa yang dilaluinya membuat eksistensi Rosie sebagai perempun yang diperlakukan tidak adil sangat terasa dalam novel ini. Proses pencarian jati diri Rosie menjadikannya sosok yang mandiri. Rosie ingin lepas dari pengaruh kekuasaan dan kekayaan keluarganya. Rosie juga memiliki kepedulian yang tinggi terhadap lingkungannya. Dia merupakan sosok yang aktif memperjuangkan nasib rakyat dengan caranya sendiri. Rosie terlibat aktif dalam organisasi mahasiswa kemahasiswaan dan aktif menyuarakan kebenaran. Di sisi lain, Rosie juga berjuang mencari informasi tentang penyebab kematian kedua orang tua kandungnya.

Fakta-fakta tentang gaya hidup orang-orang kaya perkotaan, perjuangan seorang gadis dalam mencari keluarganya, berkuasanya rezim orde baru, hingga fakta tragedi kemanusiaan menjadi bagian dalam novel ini. Atas dasar tersebut, penulis tertarik meneliti simbol semiotik yang berupa ikon, indeks, dan simbol menggunakan teori Pierce.

Objek dari kajian ini adalah novel Anomie karya Rilda A.Oe. Taneko. Tujuan dari kajian ini adalah untuk mendeskripsikan dan menjelaskan: (1) tanda yang meliputi ikon, indeks, dan simbol dalam novel Anomie karya Rilda A.Oe. Taneko berdasarkan analisis semiotik; (2) makna tanda berupa ikon, indeks, dan simbol dalam novel Anomie karya Rilda A.Oe. Taneko.

Anomie berasal dari bahasa yunani a berarti "tanpa", nomos berarti aturan atau hukum. Bila merujuk pada novel karya Rilda, Anomie seolah merujuk pada ketiadaan norma dalam penggabungan karyanya yang terdiri atas 34 bagian menjadi satu kesatuan yang utuh. Oleh karena itu, untuk menangkap makna yang dihadirkan dalam setiap bagian cerita diperlukan "energi" yang besar. Anomie bisa jadi juga merujuk pada peristiwa-peristiwa yang dialami oleh tokoh utama dalam cerita yang melahirkan konflik sehingga cerita mencapai klimaks.

Rilda A. Oe. Taneko adalah penulis asal Lampung yang saat ini tinggal di Eropa. Perempuan lulusan S1 Sosiologi, Universitas Lampung ini telah beberapa kali menerbitkan karya fiksinya seperti cerita pendek 100 Faces, 100 stories 
di Newcastle-upon-tyne, dan Castle Park Stories: An Exhibition di Lancaster, Inggris. Buku-bukunya yang sudah terbit antara lain Kereta Pagi Menuju Den Haag tahun 2010.

Dengan gaya penceritaannya Rilda mencoba mengangkat tiga kejadian utama yang pernah ada di Indonesia, yakni peristiwa kerusuhan pada masa reformasi 1998, peristiwa pascareformasi, dan peristiwa Talangsari 1989. Dalam novelnya ini Rilda menyajikan bagaimana kerusuhan terjadi di tahun 1998 itu dan bagaimana peran mahasiswa di masa itu. Selain itu, Rilda juga mengisahkan beberapa peristiwa yang terjadi di, Lampung Tengah.

Dalam novelnya, Rilda A. Oe. Taneko menyajikan alur yang melompat-lompat. Lompatan alur ini disiasati oleh Rilda dengan memberi subjudul yang berbeda pada setiap bagian. Pemberian subjudul inilah yang menjadi tantangan tersendiri bagi pembaca untuk meramu cerita menjadi satu kesatuan yang utuh.

Rilda memulai ceritanya dengan prolog yang diberi subjudul "Pesta Pernikahan". Pada bagian ini diceritakan pernikahan Tante Anna yang orang Lampung dengan Om Jo yang berkebangsaan asing. Akan tetapi, pernikahan itu digelar dengan menggunakan adat Lampung yang meriah. Pada bagian satu barulah Rilda menceritakan peristiwa sejarah yang berkaitan dengan demonstrasi yang dilakukan oleh mahasiswa pada akhir September 1999 yang lebih dikenal dengan masa reformasi. Bagian satu ini diberi subjudul "Mahasiswi Berkerudung Biru".
Bagian kedua dalam novel Anomie ini bercerita tentang karut-marut yang terjadi selama berlangsungnya peristiwa reformasi yang memakan korban. Bagian ketiga bercerita tantang kesedihan yang terjadi pascareformasi. Pada bagian selanjutnya Rilda menyajikan berbagai peristiwa dan konflik yang dilami tokoh utama dengan berbagai latar dan situasi. Pada bagian akhir, Rilda menulis sebuah epilog untuk menuntun pembaca menyudahi cerita sesuai dengan imajinasi masing-masing pembaca.

Novel tersebut secara jelas mendeskripsikan beberapa fakta sejarah yang terjadi pada masa Orde Baru berkuasa hingga tergulingnya masa Orde Baru. Dalam novel Anomie itu juga diungkapkan pergerakan mahasiswa pada masa reformasi yang menentang pemerintahan saat itu.

Berdasarkan penjelasan di atas, penulis ingin mengkaji novel Anomie karya Rilda A.Oe. Taneko melalui pendekatan semiotik Pierce yang meliputi (1) ikon dalam novel Anomie karya Rilda A.Oe. Taneko; (2) indeks dalam novel Anomie karya Rilda A.Oe. Taneko; dan (3) simbol dalam novel Anomie karya Rilda A.Oe. Taneko.

Berdasarkan latar belakang penulisan ini, maka rumusan masalah pada tulisan ini adalah, (1) apa saja ikon, indeks, dan simbol yang terdapat dalam novel Anomie? (2) apa makna ikon, simbol dan indeks yang terdapat dalam novel Anomie tersebut?.

Berdasarkan rumusan masalah di atas, penelitian ini bertujuan, (1) mengetahui tanda berupa ikon, indeks, dan simbol yang digunakan dalam novel Anomie, (2) mengetahui arti, dan makna 
ikon, indeks dan simbol yang terkandung dalam novel Anomie.

Metode dalam penelitian ini bersifat deskriptif kualitatif dengan pertimbangan bahwa penjelasan membutuhkan beberapa deskripsi dari fenomena penelitian dalam bentuk katakata, kalimat, atau frasa. Pendekatan yang dipakai dalam penelitian ini adalah pendekatan semiotika yang diperkenalkan oleh Charles Sanders Piece. Teknik pengumpulan data dalam penelitian ini menggunakan teknik studi pustaka.

\section{Landasan Teori}

Novel adalah salah satu karya sastra yang di dalamnya berisi tentang pelajaran kehidupan. Novel merupakan rangkaian cerita yang cukup panjang, di dalam novel mengandung rangkaian cerita kehidupan tokoh-tokohnya. Selain itu pula, novel merupakan salah satu wujud dari karya imajinasi manusia yang dituang dalam bentuk tulisan. Penulis merangkaikan kalimat demi kalimat yang dapat mewakili imajinasinya untuk membentuk sederetan realitas yang ada dalam keseharian manusia. Cerita yang terdapat dalam novel merupakan kisah hidup dan berbagai peristiwa kehidupan yang dialami oleh tokoh-tokoh cerita yang juga memerankan berbagai karakter tersendiri. Hal ini didukung oleh pendapat Sumardjo (1984: 65) yaitu sedang novel sering diartikan sebagai hanya bercerita cerita tentang bagian kehidupan seseorang saja, seperti masa menjelang perkawinan setelah mengalami masa percintaan; atau bagian kehidupan waktu seseorang tokoh mengalami krisis dalam jiwanya, dan sebagainya.
Menurut Nurgiyantoro (2012:15), novel adalah karya bersifat realistis, yang mengacu pada realitas yang lebih tinggi dan psikologi yang lebih mendalam. Maksudnya, novel merupakan hasil karya imajinasi pengarang yang bersifat realistis yaitu sesuatu yang ada dalam kehidupan manusia dan mengandung nilai-nilai luhur yang dapat diaplikasikan dalam kehidupan para pembaca.

Semiotik merupakan salah satu teori dalam pengkajian budaya termasuk sastra di dalamnya. Karya sastra merupakan sistem tanda yang mempergunakan medium bahasa (Abrams, 1981: 770). Oleh karena itu, untuk menganalisis struktur sistem tanda serta mengungkap makna tandatanda yang digunakan sastrawan tersebut diperlukan ilmu/teori tentang tanda yaitu semiotik.

Semiotika berasal dari kata Yunani, semeion, yang berarti tanda. Semiotika adalah ilmu yang mempelajari tentang tanda. Tanda-tanda tersebut menyampaikan suatu informasi sehingga bersifat komunikatif. la mampu menggantikan sesuatu yang lain yang dapat dipikirkan atau dibayangkan, cabang ilmu ini semula berkembang dalam bidang bahasa, kemudian berkembang pula dalam bidang seni rupa dan desain komunikasi visual (Tinarbuko, 2008: 16). Peletak dasar teori semiotik adalah Ferdinand de Saussure dan Charles Sander Pierce. Jika teori semiotik Saussure bersifat semiotik struktural, teori Pierce lebih bersifat semiotik analitis (Nurgiantoro, 2000: 53).

Istilah semiotika pertama kali terlahir dari buah pemikiran filsuf Amerika yang bernama Charles Sanders 
Pierce. Charles Sanders Pierce (18391914, Filsuf Amerika), lahir di Cambridge, Massachusetts pada tahun 1839. Pierce menjadikan logika sebagai landasan teorinya. Teori Pierce kemudian dikembangkan oleh Charles Williams Morris (1901-1979) dalam bukunya Behaviourist Semiotics, Sudjiman \& Zoest (dalam Pateda, 2001:32). Ia menyamakan semiotika dengan logika. Dick Hartoko (1984:42) memberi batasan semiotika adalah bagaimana karya itu ditafsirkan oleh para pengamat dan masyarakat lewat tanda, simbol atau lambang. Aart Van Zoest (dalam Sudjiman, 1992:5) mendefinisikan semiotika adalah studi tentang tanda dan segala yang berhubungan dengannya; cara berfungsinya; hubungannya dengan tanda-tanda lain, pengirimannya, dan penerimaannya oleh mereka yang mempergunakannya.

Pierce mengatakan (dalam Sobur, 2009: 160-162) bahwa dalam teori semiotika walaupun simbol atau lambang merupakan salah satu kategori tanda (sign), dan Ia menyatakan bahwa tanda (signs) terdiri atas ikon, indeks, dan simbol, tetapi simbol dan tanda adalah dua hal yang berbeda. Secara garis besar, perbedaan itu terletak dari pemaknaan keduanya terhadap objek-objek yang ada di sekelilingnya. Tanda berkaitan langsung dengan objek dan tanda dapat berupa benda-benda yang merupakan keadaan. Ikon adalah tanda yang penanda dan petandanya menunjukan ada yang bersifat alamiah, yaitu penanda sama dengan petandanya. Hubungan itu adalah hubungan persamaan, misalnya gambar orang, potret atau lukisan. Indeks adalah tanda yang penanda dan petandanya menunjukan adanya hubungan alamiah yang bersifat kausalitas (sebab-akibat). Simbol adalah penanda dan petanda yang tidak menunjukan adanya hubungan alamiah atau bersifat arbitrer (semau-maunya). Arti tanda itu ditentukan oleh konvensi (berdasarkan kesepakatan).

Pierce mengemukakan bahwa "tanda hanya berarti tanda apabila ia berfungsi sebagai tanda" (Zoest, 1993:10). Dapat disimpulkan bahwa kehadiran tanda itu harus ada yang mendasari kemunculannya, tidak dengan sendiriannya. Bagi Pierce fungsi esensial tanda adalah membuat efisiensi, baik dalam komunikasi kita dengan orang lain, maupun dalam pemikiran dan pemahaman kita tentang dunia (Zoest, 1993:11).

Kajian ini menggunakan pendekatan semiotika Charles Sanders Pierce sebagai landasan teori. Teori semiotika Pierce bersifat pragmatik, yakni semiotika yang mempelajari hubungan di antara tanda-tanda dengan interpreternya atau para pemakainya (Budiman, 2011:4).

\section{Pembahasan}

\subsection{Ikon dalam Novel Anomie}

Ikon dalam novel ini berdasarkan hasil kajian penulis meliputi ikon lembaga pendidikan (sekolah dan universitas) sebagai penanda sosial. Hal ini terdapat dalam kutipan novel berikut ini.

"Guruku baru saya memberitahu kalau aku tidak perlu mengikuti Ujian Masuk Perguruan Tinggi (UMPTN). Karena hasil pencapaian hasil kerjaku selama ini, aku punya kesempatan untuk masuk universitas yang kuinginkan melalui jalur khusus." (Taneko, 2017: 84) 
"Papa tampak terluka. Aku telah memutuskan untuk kuliah di Sumatra."

"Aku ingin mencari orangtua kandungku."

(Taneko, 2017: 100)

Dalam novel ini dideskripsikan bagaimana suasana kondisi lembaga pendidikan di kota besar dan sekolah yang secara tidak langsung dikhususkan untuk warga keturunan. hal tersebut tedapat dalam kutipan berikut

"Kemudian guru-guru mengawal kami satu demi satu ke keluarga di luar gerbang sekolah. Hampir semua mengangis. Saat giliran meilany keluar gerbang tiba-tiba saja datang tujuh orang laki-laki, entah dari mana. Mereka berbadan besar dan berambut pendek. Mereka meneriaki kami, 'Cinacina kaya sialan, tangkap mereka"'

(Taneko, 2017: 188)

Pada kutipan cerita tersebut, katakata 'cina-cina' secara tidak langsung menggambarkan bahwa Meilany bersekolah di sekolah yang mayoritas siswanya warga keturunan.

Selain lembaga pendidikan, terdapat juga ikon lembaga sosial, seperti panti asuhan. Hal tersebut terdapat dalam kutipan berikut ini

"Kami, Mama dan aku, mengadopsimu dari Panti Asuhan. Kami mengambilmu dari sebuah pulau dekat perkampungan nelayan, di ujung teluk di bagian selatan Sumatra. Kamu sangat manis hingga kami jatuh cinta saat pertama kali kami melihatmu. Dengan mata seperti milikmu, siapa yang tidak akan jatuh?"( Taneko, 2017: 98).
"Papa dan mama mengambilku dari sebuah provinsi di ujung selatan sumatra. Aku diambil dari panti asuhan di tepi laut. Papa tidak akan mengatakan di mana tepatnya panti asuhan itu berada." (Taneko, 2017: 101)

Kutipan diatas bercerita tentang panti asuhan dimana Rosie pernah menjadi penghuni panti sosial, sebelum diadopsi oleh keluarga angkatnya.

Selain panti asuhan, tempat hiburan juga merupakan ikon yang terdapat dalam novel ini. Tempat-tempat hiburan seperti pusat perbelanjaan, diskotik, bioskop, dan salon. Hal tersebut terdapat dalam kutipan berikut ini.

“Tante Anna kerap mengajak Meilany dan aku untuk berbelanja, berdisko, nonton ke bioskop, dan pergi ke salon. Tante Anna tak pernah alpa mengajak kami untuk yang kusebut terakhir. Hampir setiap penghujung minggu kami pergi ke salon kecantikan, cream bath, lulur, dan spa. Biasanya kami menghabiskan sehari penuh di salon"

(Taneko, 2017: 51)

Kutipan novel diatas menggambarkan kehidupan konsumtif yang dilakukan oleh tokoh-tokoh sepeti Tante Anna, Rosie, dan Meilany. Diskotik dan hiburan malam pada umumnya adalah hiburan masyarakat kalangan atas untuk mencari kesenangan dengan menghambur-hamburkan uang mereka. Salon juga merupakan ikon bahwa masyarakat kalangan atas, rela mengeluarkan uang banyak demi terlihat cantik. Hal tersebut terlihat dari penggunaan kata, ... kerap mengajak ... untuk berbelanja, tak pernah alpa mengajak ... (ke salon), dan pergi ke disko malam ini. 


\subsection{Indeks dalam Novel Anomie}

Novel Anomie karya Rilda A.Oe. Taneko memiliki beberapa tanda indeks. Tanda indeks dalam kajian ini sebagai berikut. Pertama, indeks prilaku tokohtokoh dalam novel ini seperti mempunyai kekuasaan, sombong, serakah dan kekhawatiran.

Kekuasaan dalam novel ini digambarkan dengan keluarga angkat Rosie, yang menjadi salah satu orang terdekat penguasa negeri, dengan mudahnya keluarga angkat Rosie menerima dan mewujudkan keinginannya.

"Pakde meletakkan tangannya di pundak Papa, mencoba memberinya kekuatan, meski penyataanya Pakde pin terlihat berduka."

"Pakde adalah mantan presiden negara ini." (Taneko, 2017: 41)

Kata 'mantan presiden' pada kutipan cerita tersebut menegaskan bahwa pamannya Rosie adalah orang yeng pernah berkuasa di negeri ini.

Kesombongan dalam novel ini digambarkan dengan sosok Om Jo, yang selalu mengandalkan kekuasaannya sebagai orang dekat penguasa negeri. Tidak jarang perbuatan salah Om Jo, bisa menjadi benar dengan keterlibatan orang-orang disekitarnya. Hal tersebut dapat terlihat dalam kutipan berikut.

“Aku menelpon sebentar boleh ya?' tanyanya. Lalu tanpa menunggu jawaban, Oom Jo beranjak ke arah bar dan meminjam telepon. Ia kemudian melambai, meminta pria yang tadi membentaknya datang, dan menyerahkan gagang telepon padanya. Oom Jo kembali merebahkan tubuh ke sofa dan menyilangkan kaki. Ia melihat ke arah bar dan tampak menunggu"

"Keterkejutan bagi kawan-kawannya yang lain, pria itu menunduk dan meminta maaf pada Oom Jo. Meski pria itu terlihat jauh lebih tua dari Oom Jo, dia memanggil Oom Jo dengan sebutan abang"(Taneko, 2017: 56).

Bentuk kekhwatiran terlihat dalam tokoh Rosie saat masih menjadi aktivis mahasiswa. Hal ini tergambar saat Rosie berpikir jika dia sedang diawasi oleh tentara, karena Rosie salah satu orang 'penting' dalam organisasi mahasiswa yang diikutinya, hingga akhirnya Rosie tahu bahwa tentara yang mengikuti dan mengejarnya bukan urusan organisasi mahasiswanya, melainkan suruhan Om Jo, dengan maksud untuk membunuh Rosie.

"Ada tentara yang mengejarmu, Rosie. Itu memang benar. Taapi bukan seperti yang kamu kira." Tante Anna terdiam sesaat. Lalu ia berbisik, "Cuma Jo saja. Jo yang membayar dan memerintahkan orang-orang untuk menculikmu"

(Taneko, 2017: 193).

"Sudah lama Jo cemburu padamu, Rosie. Sebalum kamu datang, Jo selalu menjadi pusat perhatian seluruh anggota keluarga. Jo mersa kamu merampas kasih sayang keluarga-nya dari dia. Dia makin membencimu ketika abangnya menamparnya" (Taneko, 2017: 193).

Kedua, indeks yang ditampilkan adalah gaya hidup masyarakat lapisan atas. Gaya hidup kalangan atas digambarkan oleh tokoh-tokoh dalam novel ini dengan cara menghamburhamburkan harta demi mendapatkan 
kesenangannya, seperti pergi ke diskotik setiap malam demi mencari kesenangan.

“...Dan sejak itu, menjadi kebiasaan kami untuk menghabiskan sabtu malam di kafe, bar, pub dan diskotek disekitar selatan ibukota"(Taneko, 2017: 51)

Ketiga, indeks yang ditampilkan adalah aktivitas atau pekerjaan yang dilakukan tokoh-tokoh dalam novel ini. Pada novel ini terdapat beberapa aktivitas yang dilakukan oleh tokohtokohnya seperti Rosie yang menjadi aktivis mahasiswa.

"Kami sedang menggelar aksi di depan markas tentara, saat kerusuhan pecah. Peluru tajam ditembakkan dari arah pemakaman umum di sebelah markas. Aku dapat melihat beberapa tentara bersembunyi di balik hijau daun dan putihnya bunga kamboja, tepat di belakang pagar kuburan" (Taneko, 2017: 8).

Pada kutipan novel diatas menggambarkan bagaimana suasana unjuk rasa yang dilakukan oleh mahasiswa berakhir dengan kerusuhuan.

Indeks aktivitas juga terlihat pada pekerjaan ayah angkat Rosie yang menjadi pemilik perkebunan di Sumatra.

"Sejak Opa menginggal, Papa mewarisi semua kekayaan keluarga bersama Mama, yang terlahir di keluarga intelektual yang terkenal (kebanyakan sanak saudara mama bekerja sebagai akademisi dan peneliti), mereka menjadi bagian dari komunitas yang memiliki hak istimewa di negeri ini." (Taneko, 2017: 58)

"Selain rumah, Papa juga mewarisi tanah perkebunan, pabrik, dan perusahaan di Sumatra dan Kalimantan." (Taneko, 2017: 58)

Kutipan cerpen diatas menggambarkan bagaimana kekayaan yang dimiliki oleh ayah angkat Rosie. Katakata seperti "mewarisi semua kekayaan keluarga" dan kalimat "tanah perkebunan, pabrik, dan perusahaan di Sumatra dan Kalimantan" menandakan bagaimana banyakya harta kekayaan yang dimiliki oleh keluarga angkat Rosie.

Indeks keempat yang ditampilkan novel ini adalah penampilan fisik aparat pemerintah. Hal ini terlihat dalam kutipan berikut ini.

"Aku menyaksikan apa yang dilakukan tentara-tentara itu di dusun kita dari gubukku. Aku berlari ke dusun terdekat untuk mencari pertolongan. Tapi semuanya sudah terlambat..." Pembuat gula mendesah. Matanya Berkabut" (Taneko, 2017: 179).

Dalam novel ini juga tergambar beberapa bagian tentang ciri-ciri atribut yang biasanya dikenakan oleh tentara. Hal ini terdapat dalam kutipan berikut ini.

"Umi tidak menjawab. Ia hanya menunjuk pada beberapa pria berseragam hijau. Mereka menggunakan sepatu bot hitam dan membawa senapan. Mereka berteriak, membentak, mendorong dan menendang beberapa tetangga kami" (Taneko, 2017: 174)

Dalam kutipan novel tersebut memperlihatkan bagaimana ciri-ciri yang umumnya dipakai oleh tentara, yaitu memakai sepatu bot hitam, memakai seragam hijau, dan membawa senapan. 
Indeks yang kelima yang terdapat dalam novel ini adalah organisasi kemahasiswaan.

"Kami sedang menggelar aksi di depan markas tentara, saat kerusuhan pecah. Peluru tajam ditembakkan dari arah pemakaman umum di sebelah markas. Aku dapat melihat beberapa tentara ber-sembunyi di balik hijau daun dan putihnya bunga kamboja, tepat di belakang pagar kuburan." (Taneko, 2017: 8)

"Hamzah adalah kawan kami. Dia sangat aktif di organisasi. Ketika kami menginisiasi aksi kemarin, pihak universitas dan BEM bersikap sangat tidak mendukung. (Taneko, 2017)

Kutipan di atas menjelaskan bagaimana Rosie bergabung dengan organisasi kemahasiswaan yang tidak disukai oleh pihak kampus dan beberapa elemen mahasiswa lainnya, hal ini dikarenakan organisasi Rosie kerap melakukan aksi unjuk rasa yang terakhir dengan kerusuhan.

\subsection{Simbol dalam Novel Anomie}

Simbol merupakan sebuah tanda yang berdasarkan pada konvensi, peraturan atau perjanjian yang disepakati bersama, dalam novel Anomie ini terdapat beberapa simbol seperti, simbol kekayaan dalam novel ini terlihat bagaimana kekayaan yang dimiliki oleh keluarga angkat Rosie.

"Sejak Opa meninggal, Papa mewarisi semua kekayaan keluarga bersama Mama, yang terlahir di keluarga intelektual yang terkenal (kebanyakan sanak saudara mama bekerja sebagai akademisi dan peneliti), mereka menjadi bagian dari komunitas yang memiliki hak istimewa di negeri ini."

(Taneko, 2017: 58)

"Selain rumah, Papa juga mewarisi tanah perkebunan, pabrik, dan perusahaan di Sumatra dan Kalimantan." (Taneko, 2017: 58)

Keluarga angkat Rosie memiliki perusahaan perkebunan yang tersebar di negeri ini. Simbol kekuasaan dalam novel ini terlihat dari ayah angkat Rosie dan Om Jo, yang dengan mudah mengatur aparat keamanan dan penegak hukum demi mempermudah urusan mereka.

Simbol persahabatan dalam novel ini tergambar oleh tokoh Rosie dan Meilany yang sudah terjalin sejak masih kecil, selain itu ada juga kisah persahabatan antara Rosie dengan Ella, teman indekosnya Rosie.

"Meilany tidak menyadari kehdiran Tante Anna dan aku. Dia sibuk dengan kameranya, mengambil gambar gereja, dan gerbang batu menuju kuburan Wordsworth."

(Taneko, 2017: 147)

"Meilany sangat terkejut."

“' 'Rosie?!' seru Meilany tak percaya” Aku terus memeluknya. Aku menangis bahagia.

"Tante Anna?!"

(Taneko, 2017: 147)

Simbol cinta kasih dalam novel ini terlihat pada bagaimana orang tua angkat Rosie yang sangat sayang kepadanya.

"Kami, Mama dan aku, mengadopsimu dari Panti Asuhan. Kami mengambilmu dari sebuah pulau dekat perkampungan nelayan, di ujung teluk di bagian selatan Sumatra. Kamu sangat manis hingga kami jatuh cinta saat pertama kali kami melihatmu. 
Dengan mata seperti milikmu, siapa yang tidak akan jatuh?"

(Taneko, 2017: 98)

Selain orang tua angkatnya, tante Anna istri dari Oom Jo, juga sangat menyayangi Rosie. Selain keluarga angkat Rosie ada juga Andi yang dengan diam-diam mengagumi dan mencintai Rosie. Sifat Andi itu merupakan simbol cinta kasih.

Simbol pengorbanan dalam novel ini terlihat pada pengorbanan seorang ayah kandung (Abah) Rosie saat terjadi penyerangan oleh aparat terhadap dusunnya, begitu pula dengan Umi (ibu Rosie) yang memperlihatkan pengorbanan dirinya untuk menelindungi anaknya (Rosie).

"Lari ke mushola, berlindung di

sana. Kalian akan baik-baik saja,"

kata Abi dengan suara bergetar.

"Kamu mau kemana?" Tanya Umi, mulai terisak

"Aku harus membantu tetangga kita. Mereka melawan tentara."

"Jangan tinggalkan kami," tangis Umi.

"Kamu tahu aku tidak punya pilihan," ujar Abi lemah, "Maafkan aku."

(Taneko, 2017: 175)

\section{Simpulan}

Tanda ikon, indeks, dan simbol berfungsi untuk menggambarkan dan memperjelas cerita. Selain itu, penggunaan ikon, indeks, dan simbol juga berfungsi untuk memperindah penggunaan bahasa, sehingga pembaca lebih menikmati isi dari novel Anomie ini.

Setelah melakukan analisis novel Anomie melalui pendekatan semiotik didapati beberapa simpulan sebagai berikut. Dalam novel Anomie ini, ikonikon berupa lembaga pendidikan digambarkan dengan universitas tempat Rosie menimba ilmu. Panti asuhan tempat Rosie tinggal setelah kerusuhan yang merenggut nyawa ayah dan ibu. Tempat-tempat hiburan yang digambarkan dengan diskotik, bioskop, dan salon.

Dalam novel ini terdapat lima indeks yaitu indeks prilaku tokoh-tokoh, gaya hidup masyarakat lapisan atas, aktivitas atau pekerjaan, penampilan fisik aparat pemerintah (tentara), dan organisasi kemahasiswaan.

Dalam novel Anomie ini terdapat lima simbol, yakni:

(1) simbol kekayaan yang digambarkan dengan harta yang berlimpah dari keluarga angkat Rosie dan mempunyai banyak perusahaan;

(2) simbol kekuasaan dalam novel digambarkan dengan ayah angkatnya Rosie yang masih menjadi keluarga penguasa negeri; simbol kekuasaan juga digambarkan dengan mudahnya keluarga Rosie 'mengatur' aparat demi mempermudah urusan meraka;

(3) Simbol persahabatan dalam novel ini digambarkan dengan persahabatan antara Rosie dan Meilany yang terjalin sejak usia mereka kecil; dan

(4) Simbol cinta kasih dalam novel ini digambarkan dengan rasa sayang orang tua angkat terhadap Rosie, selain orang tua angkatnya, tante Anna juga sangat menyayangi Rosie, serta Andi yang mengagumi dan mencintai Rosie.

(5) Simbol yang terakhir yang menjadi penambah dalam novel ini adalah pengorbanan, simbol pengorbanan ini digambarkan 
dengan pengorbanan ayah kandung Rosie yang mengorbankan dirinya demi melindungi keluarganya.

Dari keenam simbol tersebut kita dapat melihat adanya keragaman dalam novel Anomie, bahwa kehidupan selalu memberikan kisah terbaiknya. Selalu terdapat cinta kasih antar manusia dalam kehidupan yang nyata. Begitupun digambarkan dalam novel Anomie ini yaitu terdapat cinta kasih tulus para orang tua kepada anak, sekalipun anaknya bukan darah daging sendiri, melainkan anak angkat; seperti kisah Rosie yang sangat disayangi kedua orang tuanya.

\section{Daftar Pustaka}

Abrams, M.H. (1981). A Glossary of Literary Term. New York: Holt, Rinehart and Winston.

Aminudin. (1995). Pengantar Apresiasi Karya Sastra. Bandung: Sinar Baru.

Barthes, Roland. (2007). Petualangan Semiologi (diterjemahkan oleh: Dr. Wening Udasmoro). Yogyakarta: Pustaka Pelajar.

Budiman, K. (2011). Semiotika Visual: Konsep, Isu, dan Problem Ikonisitas. Yogyakarta: Jalasutra.

Endraswara, Suwardi. (2008). Metodologi Penelitian Sastra. Yogyakarta: MedPress.

Eco, Umberto. (1997). A Theory Of Semiotics. Bloomimgton: Indiana University. Press.
Hoed, Benny H. (2011). Semiotik dan Dinamika Sosial Budaya edisi ke-3. Depok: Komunitas Bambu.

Hartoko, Dick. (1984). Manusia dan Seni. Yogyakarta. Kanisius.

Nurgiyantoro, Burhan. (2000). Teori Pengkajian Fiksi. Yogyakarta: Gadjah Mada University Press.

Pateda, Mansoer. (2001). Semantik Leksikal. Jakarta: Rineka Cipta.

Pradopo, Rahmat Djoko. (2001). Metodologi Penelitian Sastra, Yogyakarta: Hinindita.

Pradopo, Rahmat Djoko. (1995). Beberapa Teori Sastra, Metode Kritik dan Penerapannya. Yogyakarta: Pusta-ka Pelajar.

Sobur, Alex. (2009). Semiotika Komunikasi. Bandung. Remaja Rosdakarya.

Sudjiman, Panuti. (1992). Memahami Cerita Rekaan. Jakarta: Pustaka Jaya.

Sudjiman, Panuti dan Aart Van Zoest. (1992). Serba-serbi Semiotika. Jakarta: PT Gramedia Pustaka Utama.

Semi, M. Atar. (1988). Anatomi Sastra. Padang: Angkasa Raya.

Semi, M. Atar. (1990). Metode Penelitian Sastra. Bandung: Angkasa.

Stanton, Robert. (2007). Teori Fiksi. Yogyakarta: Pustaka Pelajar. 
Sumardjo, Jakob. (1984). Masyarakat dan Sastra Indonesia. Jakarta: Nur Cahaya.

Taneko, Rilda. A.OE. (2017). Anomie. PT. Koekoesan. Jakarta.

Tinarbuko, Sumbo. (2008). Semiotika Komunikasi Visual. Yogyakarta: Jalasutra.

Wellek, Rene dan Austin Warren. (1995). Teori Kesusastraan. (diterjemahkan oleh Melani Budianta). Jakarta: Gramedia.

Waluyo, Herman J. (2002). Pengkajian Sastra Rekaan. Salatiga: Widyasari Press.

Van Zoest, Aart. (1993). Semiotika: Tentang Tanda, Cara Kerja dan Apa yang Kita Lakukan Dengannya (diterjemahan oleh Ani Soekowati). Jakarta: Sumber Agung. 